\title{
Human rights reporting under increasing institutional pressure
}

\author{
Frank Hubers, Thomas Thijssens
}

\author{
\begin{tabular}{l|l|l|l} 
Received 24 January 2020 & Accepted 27 May 2020 & Published 28 July 2020
\end{tabular}
}

\begin{abstract}
In 2014, the European Union (EU) passed Directive 2014/95/EU (The Directive), requiring Public Interest Entities (PIEs) to disclose specific non-financial information in their annual reports. This study investigates how The Directive influenced sustainability reporting - in particular human rights disclosure - by taking an institutional perspective. This implies that we refrain from viewing The Directive as an isolated event, but rather as a consequence of the ongoing interaction of different forces within the institutional context. Starting from this view, we investigate how human rights disclosure has developed over the years, focussing on the institutional context in which these developments took place. We use a longitudinal research design, using content analysis to observe human rights disclosure in annual and sustainability reports during the 2002-2018 period of the Dutch financial services companies listed on the three most important Dutch stock market indexes. We find that there appears to be an increase in the extensiveness of human rights reporting after the introduction of The Directive, but that these changes in disclosure are better explained by the increasing trend over time than by The Directive itself. Our analysis of 17 years of annual reporting shows a steady linear increase in the extensiveness of human rights disclosure, with no strong deviations during the introduction of The Directive. Notwithstanding an overall increase over the years, the proportion of human rights information in both annual and sustainability reports remains fairly low.
\end{abstract}

\section{Relevance to practice}

The results of this study imply that the role of legislation in the adoption of human rights reporting is limited. However, this might be partly due to the rather undemanding nature of Directive 2014/95/EU, as well as the large average size of the sample companies.

\section{Keywords}

Human rights, sustainability reporting, non-financial disclosure, mandatory disclosure

\section{Introduction}

In 2014, the European Union (EU) passed Directive 2014/95/EU (The Directive), requiring Public Interest Entities (PIEs) to disclose non-financial information in their annual reports. The mandated information includes environmental, social and employee matters, respect for human rights, anti-corruption and bribery matters. The Directive also prescribes the types of information, including policies, and outcomes of those policies, related risks and risk management, and non-financial key performance indicators. Although the mandatory disclosure of environmental and social issues has been part of EU legislation since 2003 (which was included in the Dutch
Civil Code in 2005), this directive is more explicit in its requirements regarding the specific types of non-financial information that must be disclosed. Given the unprecedented scope, scale and level of detail of The Directive, its passage and implementation have attracted significant research attention. Most of these studies treat the EU regulation as an exogenous, regulatory shock (Carini et al. 2018; Fiechter et al. 2018; Grewal et al. 2018; Ioannou and Serafeim 2019a).

This study refrains from viewing The Directive as an isolated event. Rather, it is based on the idea that mandatory reporting rules, like voluntary reporting rules, form just one of many institutional factors. The institutional context, in which sustainability reporting decisions are 
taken, is a complex of mutually influential (inter)national institutional forces, which are represented by institutions, including companies, that exercise power via negotiation, persuasion, and confrontation (Campbell 2006). Moreover, ongoing interaction between these powers causes constant change (Campbell 2006), to which companies need to adjust in order to maintain their legitimacy.

Starting from this view, we investigate how sustainability reporting has developed over the years, focussing on the institutional context in which this development has taken place, including the recent EU-directive. Hence, we choose a longitudinal research design, focusing on one country, one sector and one type of sustainability information. That is, we focus on human rights reporting in annual and sustainability reports during the 2002-2018 period of the Dutch financial services companies listed on the three most important Dutch stock market indexes: the AEX, AMX and AScX. With this research design, we seek to discover trends in the development of this specific type of disclosure and assess the potential impact of the recent EU legislation.

We find that overall, disclosure on human rights is fairly low. In addition, the mean values for human rights disclosures after The Directive are significantly greater than before, implying an effect of The Directive. However, the results of regression analyses, in which we control for time trends, show that in fact, there is no such effect; human rights disclosure is associated only with this time trend. This corresponds with our trend analysis, showing a steady increase in human rights disclosure between 2002 and 2018. A detailed analysis of the sample companies shows that causes for these trends may be found in the complex of accumulating (inter)national institutional forces, represented by institutions exercising their powers, that together constitute the context of human rights disclosure by Dutch financial institutions.

This paper will proceed as follows. In section 2 the literature will be reviewed. Section 3 describes the methodology that was applied in this study. As a next step, section 4 will present the results. We end with some concluding remarks in section 5.

\section{Literature review}

Previous research on the implementation (or announcement) of mandatory reporting rules focuses on differences between ex-ante and ex-post periods (or treatment and control groups), suggesting an increase in the actual sustainability activities of firms (Fiechter et al. 2018), an increase in sustainability disclosure (Carini et al. 2018; Ioannou and Serafeim 2019a), and negative stock market reactions for weak reporters and positive for strong reporters (Grewal et al. 2018).

Typically, accounting studies start from the idea that managers respond to regulatory shocks by a rational assessment of the costs and benefits involved in (non-) disclosure decisions. However, an increasing body of ev- idence challenges the idea that sustainability disclosure decisions are a function of rational cost-benefit evaluations. Recent studies suggest that institutional factors influence these decisions, and show that sustainability reporting decisions are among others the result of mimicking behaviour (e.g., Nikolaeva and Bicho 2011), or even irrational behaviour, such as misinterpretations and lack of awareness (Pedersen et al. 2013). In line with the institutional view, this study departs from the idea that The Directive is an isolated event, and rather suggests that mandatory reporting rules form one of many institutional factors. Legislation may be simultaneously the cause of sustainability reporting and the result of (prior) institutional forces; that is, both sustainability reporting and legislation co-evolve, in that they mutually constitute one another (Witt and Miska 2018). The institutional context, in which sustainability reporting decisions are taken, is a complex of mutually influential institutional forces, represented by (inter)national institutions, including companies, that exercise power via negotiation, persuasion, and confrontation (Campbell 2006). Moreover, the institutional environment may constantly change as a result of ongoing interaction between these powers (Campbell 2006). Companies seek to adjust to this dynamic environment in order to maintain their legitimacy.

In the next section, we will review the sustainability reporting literature. After a broad reflection of some theoretical viewpoints that have been used, a concise review of the literature based on institutional theory will be given. Subsequently, the literature on human rights reporting will be reviewed.

\subsection{Sustainability reporting and institutional theory}

Despite a steady increase in the number of regulations across the world (KPMG et al. 2016), corporate sustainability reporting remained a largely discretionary activity in recent years. The main reason is that most regulation applied to only small fractions of companies (e.g., only the largest stock-listed companies, or companies belonging to one industry in a specific country), and prescribed only the provision of sustainability information, not what information must be provided (KPMG et al. 2016). Hence, one of the central questions for researchers in the field has been why companies engage in this largely voluntarily activity.

Accounting researchers typically consider economic arguments for voluntary disclosure (Healy and Palepu 2001). In the context of sustainability reporting, this implies that shareholders may value a company's efforts to become more sustainable, but-as outsiders-lack the information to differentiate between below-average and above-average sustainability performers. Therefore, companies with above-average performance have an incentive to voluntarily engage in sustainability disclosure in order to signal this (Verrecchia 2001) and resolve the information asymmetry. Challenging the economic perspective that the strategic choices of an organisation can be explained by a rational analysis of costs and benefits 
alone, researchers have started using institutional theory as the theoretical viewpoint for researching corporate sustainability practices (e.g., Campbell 2006; Husted and Allen 2006), and more specifically sustainability reporting (e.g., Doh and Guay 2006; Larrinaga 2007). Institutional theory regards strategic choices as the results of the social contexts in which they are made, stressing the importance of cultural beliefs and rules, represented by other organizations and institutions.

In their seminal contribution to institutional theory, DiMaggio and Powell (1983) argue that organizational practices and attitudes are becoming more homogeneous through structuration of organizational fields by states and the professions, rather than competition and need for efficiency. This isomorphic change is caused by three mechanisms. The first, coercive isomorphism, is the result of (in)formal pressures on organizations to reflect societal expectations. These include legislation and other pressures from actors, such as NGOs, and the media (Bondy et al. 2012). Second, mimetic isomorphism describes the tendency of managers to imitate other organisations (business leaders). Uncertainty due to developments such as lack of government regulation, or negative publicity (Bondy et al. 2012) is a frequent cause. Third, normative isomorphism is the result of professionalization of the industry and illustrates the tendency to conform to the inherent establishment of norms and values of this professionalization. Companies tend to conform to these pressures in order to maintain or regain their legitimacy so as to safeguard their resources (DiMaggio and Powell 1983).

In recent years, empirical studies have provided some evidence for the influence of institutional factors on sustainability reporting. Higgins et al. (2018) suggest that sustainability reporting is disseminating in clusters, rather than steadily across all businesses. Clusters may refer to what Ortas et al. (2015) label 'individual, organizational, national and transnational actors and agencies'.

At the national level, there are studies focusing on differences between country clusters or individual countries. Studies focusing on the difference in sustainability reporting between continental European and Anglo-Saxon countries, point at a comparatively lower reporting level for Continental-European countries in earlier years (Jackson and Apostolakou 2010), yet higher reporting levels in more recent years, as a result of coercive pressures from the legal stakeholder-oriented system (Gallego-Alvarez and Quina-Custodio 2017). Differences in corporate sustainability commitment are found between French and Spanish companies on the one hand, and Japanese on the other, even if all companies have adopted the UN Global Compact principles (Ortas et al. 2015). A study comparing sustainability reporting in France and Australia also shows differences; however, in high-risk industries, coercive, mimetic and normative industry pressures overrule national institutional influences (Young and Marais 2012). Pedersen et al. (2013) find evidence for the prevalence of national (coercive), rather than individual organ- izational factors in the event of the launch of mandatory reporting rules in Denmark. Contrary to the established differences in the above studies, some other studies provide evidence that institutional pressures and the resulting reporting, between countries are rather similar due to normative pressures from global schemes and actors, such as GRI, WWF and Global Compact (Ali and Frynas 2017; De Villiers and Alexander 2014).

At the organisational level, empirical studies mainly focus on differences in sustainability reporters over time. Bhimani et al. (2016) report differences in sustainability reporting between early and late adopters, due to respectively normative/coercive, and subsequent mimetic forces. Similarly, Shabana et al. (2017), find evidence for the prevalence of coercive isomorphism in the first stage ('defensive reporting'), normative isomorphism in the second stage ('proactive reporting') and mimetic isomorphism in the third stage ('imitative diffusion') of sustainability reporting adoption. Nikolaeva and Bicho (2011) find that GRI adoption is mainly driven by mimetic pressures, suggesting the importance of competitive and media pressures, and reputational factors.

A third strand of empirical studies, rather than focusing on national or organizational factors, concentrates on the specific institutional contexts in which managers operate, known as 'fields'. Higgins et al. (2018) describe fields as: '(...) groups and individuals that interact and, by so doing, collectively shape norms and expectations within that context'. Fields include contexts such as industries, strategies or sustainability issues. Empirical studies on industry contexts find that companies within the same industry differ in their reporting (Herremans et al. 2016), and that sustainability practices converge over time within an industry, and across industries only when adopted by the industry leaders (Ioannou and Serafeim 2019b). Higgins et al. (2018) analyse the interaction patterns of the actors in what they call the (sustainability) 'issue-based field' and conclude that the field attracts sustainability-committed companies on which pressure for sustainability action is exerted, whereas non-reporters have almost no interactions with this field. Bebbington et al. (2009) find that sustainable development reporting is the result of normative, rather than coercive pressures, from interactions between different institutions in a field of companies following a differentiation strategy with regards to sustainable development reporting.

\subsection{Human rights reporting}

As early as the 1970s, the UN have attempted to establish binding international rules governing the activities of firms (Ruggie 2007). The vision of the UN on the role of businesses in human rights was materialized with the Guiding Principles of Business and Human Rights in 2011. Reaffirming the role of the state as protector of human rights, it also stipulates the role of businesses as one that should respect human rights, independent of the state's obligations (McPhail and Ferguson 2016; Ruggie 
2008). Despite improved acknowledgement of human rights (risks) in corporate reporting in recent years, most reports remain silent on policies, or outcomes thereof (KPMG 2017).

Empirical studies on human rights reporting are scarce. Scant research shows that human rights disclosures are overall low for samples of the top 50 Australian financial service companies for the year 2009/2010 (Islam 2011), the largest 201 GRI-reporters in the world (Cubilla-Montilla et al. 2019), and the top 100 Australian listed companies in the context of 'modern slavery' disclosures (Christ et al. 2019). However, for a sample of multinational garment retail companies, it is shown that disclosure of specific human rights standards has increased significantly over time as a result of the development of standards by the ILO, stressing the importance of the role of International Governmental Organizations (Islam and McPhail 2011).

\section{Research approach}

\subsection{Methodology}

This study investigates how sustainability reporting has developed over the years, focussing on the institutional context, including The Directive, in which this development has taken place. Mandatory reporting rules are considered one of many institutional factors that mutually constitute one another (Witt and Miska 2018). We seek to discover trends in the development of disclosure and assess the potential impact of the recent EU legislation. With this aim in mind, the study combines a longitudinal design with a mixed methods approach. First, we analyse the institutional context in which sample companies operate, listing important events that may have influenced reporting over the years. We focus on one particular sustainability topic, human rights, since The Directive is the first reporting regulation in which human rights are mentioned explicitly. Moreover, in The Netherlands there was no legislation on human rights reporting before (Ministerie van Binnenlandse Zaken en Koninkrijksrelaties 2013).
This enables the investigation of a potential effect of The Directive. Moreover, this focus enables more profound, deeper analysis of the complex institutional environment of sustainability reporting. Second, we content analyse the annual and sustainability reports of a sample of companies over the years 2002 to 2018 for inclusion of human rights topics. The resulting data are analysed for potential trends, and subsequently used to estimate the marginal effect of The Directive on the basis of a pre-post analysis.

\subsection{Sample}

Our sample consists of all financial services companies listed on the three most important Dutch stock market indexes: the AEX, AMX and AScX, resulting in eight banks and insurance companies. All these companies are public interest entities (PIE), which are directly affected by The Directive.

The choice for The Netherlands as the case for our study is driven by the fact that developments regarding non-financial information disclosure in this country started in a rather early stage compared to most other EU-countries (Kolk et al. 2001). Financial services are an interesting sector in the light of institutional contexts of human rights disclosure, as they are increasingly held accountable for human rights infringements of their clients (DNB 2019). As a result, financial institutions in the Netherlands have been a popular target of NGO campaigns. Two initiatives, in which human rights play an important role, are in line with these developments: In 2009 the first edition of the 'Fair Finance Guide', an influential online portal informing consumers about the (lack of) sustainability of investments of banks and (in later editions) insurance companies, was launched. In 2019 the OECD published a guidance tool for the financial services sector to implement the OECD Guidelines for Multinationals (OECD 2019).

For each company, we collected the annual reports from 2002 to 2018. Table 1 shows the eight companies in in our sample in alphabetical order. Column (1) and (2) show the financial years for which annual reports were

Table 1. Descriptive statistics.

\begin{tabular}{|c|c|c|c|c|c|c|}
\hline & \multicolumn{2}{|c|}{ Annual reports available } & \multirow{3}{*}{$\begin{array}{c}\text { Year of first } \\
\text { Integrated Report } \\
\text { (3) }\end{array}$} & \multirow{3}{*}{$\begin{array}{l}\text { Nr. of years Sustainability } \\
\text { Reports included } \\
\text { (4) }\end{array}$} & \multirow{3}{*}{$\begin{array}{c}\text { Mean HR count } p / y \\
\text { (5) }\end{array}$} & \multirow{3}{*}{$\begin{array}{c}\text { Mean HR count } p / y \\
\text { (incl. SR) } \\
(6)\end{array}$} \\
\hline & From & To & & & & \\
\hline & (1) & (2) & & & & \\
\hline ABN AMRO & 2002 & 2018 & 2014 & 7 & 10.2 & 16.2 \\
\hline AEGON & 2002 & 2018 & 2011 & 8 & 10.0 & 16.0 \\
\hline BINCK & 2002 & 2018 & - & 1 & 1.4 & 1.4 \\
\hline ING & 2002 & 2018 & 2014 & 9 & 14.0 & 24.0 \\
\hline KAS & 2002 & 2018 & - & 0 & 0.3 & 0.3 \\
\hline NIBC & 2003 & 2018 & 2012 & 0 & 3.8 & 3.8 \\
\hline NN GROUP & 2002 & 2018 & 2014 & 0 & 8.2 & 8.2 \\
\hline VAN LANSCHOT & 2002 & 2018 & 2015 & 7 & 5.0 & 8.7 \\
\hline
\end{tabular}

Notes: $\mathrm{N}$ represent the number of years that reporting is available. Column (1) and (2) show the number of years for which annual reports are included. Column (3) shows the year in which the firm first switched to integrated reporting. Column (4) shows the number of years in which the firm published a separate sustainability reports. We only included sustainability reports for the years in which the firm did not publish an integrated report. The last two columns show the mean number of times the phrase 'human rights' [or the Dutch equivalent of 'mensenrechten'] was used in the main annual report (Annual, or Integrated Report) [Column (5)] and in the main annual report and sustainability report combined [Column (6)]. 
included. For all companies, we included reports for 18 financial years, with the exception of NIBC, which did not publish a digital annual report for 2002. The preferred language of reports is English: Only when no English report was available, a Dutch report was included. Sustainability reports were included for the years before companies converted to integrated reporting. Column (3) shows the year in which the company first switched to integrated reporting. Column (4) shows the number of sustainability reports included in the sample.

Column (5) shows the mean number of human rights mentions in the annual reports. Column (6) shows the main number of mentions when including sustainability reports. Since sustainability reports generally include more words on human rights than the annual report, we will use different panels to compare the two in our main analysis.

\subsection{Data and variables}

Table 2 provides an overview of the main variables, divided in two panels. Panel 1 refers to a sample with only annual and integrated reports, whereas Panel 2 refers to the whole sample, thus including sustainability reports. Our main dependent variable is the number of times the phrase 'human rights' or the Dutch equivalent 'mensenrechten' is used in the annual report, expressed as a ratio per 10,000 words, to control for variation in the size of annual reports. The statistics of this measure are shown in Row (3) and (7). The use of this variable is based on the assumption that the more the term is applied in annual reports, the more emphasis an organisation places on human rights reporting. As a complementary measure, we also use an index developed by Pencle and Mălăescu (2016), shown in Row (4) and (8). This validated index is a dictionary containing almost 300 words and phrases that are strongly associated with human rights reporting. Pencle and Mălăescu (2016) developed it by analysing the texts of Initial Public Offerings. As this index does not contain the term 'human rights,' it is complementary to our human rights word count. A disadvantage of this measure is that only English reports can be included, resulting into a smaller sample.

\section{Results}

\subsection{Institutional context}

Table 3 shows the result of our analysis of the institutional context of human rights reporting by Dutch financial institutions between 2002 and 2018. We searched for the major events and developments over the past three decades that may have pressured the companies in our sample, making use of the following sources: official government information sources ${ }^{1}$ and Dutch media (via the Nexis database). These factors are displayed in chronological order. The table shows examples of coercive (such as: growth of SRI, legislation, GRI, OECD (Matten and
Moon 2018; Shabana et al. 2017)), mimetic (e.g., business coalitions for CSR, Global Compact (Matten and Moon 2018)) and normative (e.g., initiatives by professional associations (Matten and Moon 2018)) pressures.

What Table 3 clearly shows is that EU Directive is only one of many factors that could have influenced human rights reporting. It also shows that the institutional context, in which human rights reporting decisions are taken, is a complex of constantly changing (inter)national institutional forces, represented by institutions, including companies, that exercise power via negotiation, persuasion, and confrontation. Moreover, analysing the historical developments that occurred before The Directive was implemented, we cannot exclude that both The Directive and human rights reporting are the result of a changing institutional context.

\subsection{Human Rights reporting}

Based on the increasing pressures on financial institutions over the years as shown in Table 3, one would expect to observe a constant increase in the reporting on human rights. In this subsection, we will explore potential trends.

Figure 1 explores the extent to which the sample companies reported on human rights over the years. It plots the proportion of firms that mention human rights at least once in their annual or sustainability report against the subsequent reporting years. Panel 1 shows the trend for annual and integrated reports only, Panel 2 also includes the sustainability reports. The figure clearly shows an increasing trend in human rights reporting over time, starting with $29 \%$ of the companies mentioning human rights in 2003 increasing to $100 \%$ in 2015 and beyond. The dashed vertical lines on the $\mathrm{x}$-axis represent the year The Directive was announced, and its inclusion in the Dutch

Figure 1. Proportion of firms per financial year that mention 'human rights' in their reports. Notes: Graph shows the proportion of reports in our sample that mentioned the term 'human rights' [or Dutch equivalent 'mensenrechten'] at least once in that financial year. Panel 1 only includes the main reports (Annual Report or Integrated Report) of each firm (maximum 1 per year); Panel (2) also includes sustainability reports for the years in which the firm did not publish an integrated report.

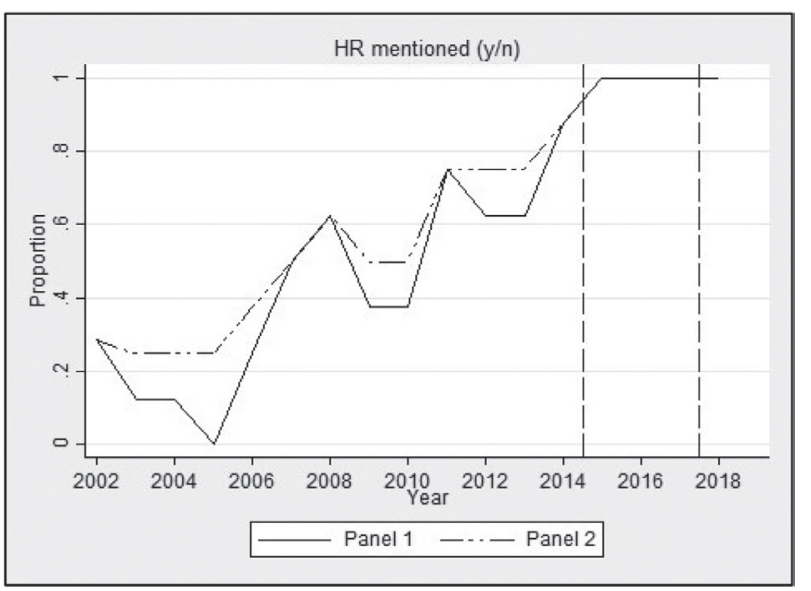


Table 2. Summary statistics.

\begin{tabular}{|c|c|c|c|c|c|c|c|}
\hline & & $\begin{array}{c}\text { (1) } \\
\text { Mean }\end{array}$ & $\begin{array}{l}\text { (2) } \\
\text { SD }\end{array}$ & $\begin{array}{l}\text { (3) } \\
\text { Min }\end{array}$ & $\begin{array}{c}\text { (4) } \\
\text { Median }\end{array}$ & $\begin{array}{c}\text { (5) } \\
\text { Max }\end{array}$ & $\begin{array}{l}\text { (6) } \\
\mathbf{N}\end{array}$ \\
\hline \multicolumn{8}{|c|}{ Panel 1: Excl. sustainability reports } \\
\hline (1) & HR mentioned $(\mathrm{y} / \mathrm{n})$ & 0.6 & 0.5 & 0 & 1 & 1 & 135 \\
\hline (2) & HR word count & 4.6 & 8.7 & 0 & 1 & 59 & 135 \\
\hline (3) & HR count per 10,000 words & 0.5 & 1.1 & 0 & 0.1 & 6.7 & 135 \\
\hline (4) & HR index & 245.7 & 45.3 & 18.1 & 247.4 & 382.6 & 126 \\
\hline \multicolumn{8}{|c|}{ Panel 2: Incl. sustainability reports } \\
\hline (5) & HR mentioned $(\mathrm{y} / \mathrm{n})$ & 0.6 & 0.5 & 0 & 1 & 1 & 167 \\
\hline (6) & HR word count & 7.2 & 12.1 & 0 & 1 & 65 & 167 \\
\hline & HR count per 10,000 words & 1.8 & 3.6 & 0 & 0.1 & 22.3 & 167 \\
\hline & HR index & 268.0 & 75.5 & 18.1 & 251.4 & 526.8 & 144 \\
\hline
\end{tabular}

Notes: Panel 1 only includes the main annual reports (Annual Report or Integrated Report) of each firm (maximum 1 per year); Panel (2) also includes sustainability reports for the years in which the firm did not publish an integrated report. Row (1) and (5) shows the proportion of annual reports that mentions 'human rights.', Row (2) and (6) the number of times the phrase 'human rights' (or Dutch equivalent 'mensenrechten') was mentioned in an annual report, and Row (3) and (7) the number of times the phrase was used per 10,000 words. In Row (4) and (8), the Variable HR Index represents the word count, using the human rights dimension of the CSR dictionary developed by Pencle and Mălăescu (2016), expressed as a ratio per 10,000 words (only for reports in English).

Table 3. Historical developments affecting sustainability reporting by financial institutions in the Netherlands.

\begin{tabular}{|c|c|}
\hline Year & Development \\
\hline 1976 & OECD Guidelines for Multinational Enterprises \\
\hline 1977 & ILO adopts Tripartite Declaration of Principles concerning Multinational Enterprises and Social Policy \\
\hline 1995-1999 & controversies in media about multinationals doing business with dictatorial regimes, such as Turkey, China, Burma, Cuba. \\
\hline 1998 & $\begin{array}{l}\text { Project 'multinationals and human rights' with NGOs (Amnesty, Pax Christi), scientists and } 9 \text { large listed companies (among } \\
\text { which ABN AMRO and ING) }\end{array}$ \\
\hline 1999-2005 & Exponential growth of socially responsible investment funds \\
\hline 2000 & $\begin{array}{l}\text { Report Socio Economic Council (SER) on the roles of the various stakeholders, including government, in promoting CSR. } \\
\text { Advice to develop sustainability reporting guidelines. }\end{array}$ \\
\hline 2000 & GRI G1 (2002: G2 introduced and HQ moved to Amsterdam) \\
\hline 2000 & UN Global Compact \\
\hline 2000-2002 & ABN AMRO, ING, Aegon launch socially responsible investment funds \\
\hline 2001 & $\begin{array}{l}\text { Memorandum of the secretary of state to the Dutch house of representatives, based on SER report, expressing government's } \\
\text { view on CSR; goal: stimulating discussion with businesses. }\end{array}$ \\
\hline 2003 & $\begin{array}{l}\text { Non-binding recommendations on sustainability reporting by the Dutch Accounting Standards Board based on } 2000 \text { SER- } \\
\text { report and GRI }\end{array}$ \\
\hline 2003 & $\begin{array}{l}\text { EC Directive 2003/51/EC, which requires inclusion of relevant non-financial KPI's, including explicitly mentioned only } \\
\text { environmental and employee matters, in the consolidated annual report. }\end{array}$ \\
\hline 2004 & $\begin{array}{l}\text { First Transparency Benchmark by the Ministry of Economic Affairs, naming companies and benchmarking their individual } \\
\text { sustainability reporting }\end{array}$ \\
\hline 2005 & 2003/52/EC included in Dutch Civil Code (Titel 9 BW2). Comply or explain basis. \\
\hline 2007-2011 & Credit crisis \\
\hline 2008 & $\begin{array}{l}\text { Dutch Corporate Governance Code: management includes relevant societal aspects of doing business in the annual } \\
\text { report. Comply or explain basis. }\end{array}$ \\
\hline 2009 & First edition of the Fair Banking Index creates media attention; banks (and in later editions insurers) \\
\hline 2011 & UN Guiding Principles on Business and Human Rights (UNGP) \\
\hline 2013 & $\begin{array}{l}\text { EU Directive 2013/34/EU, which requires inclusion of relevant non-financial KPI's, including explicitly mentioned only } \\
\text { environmental and employee matters, in the management report. }\end{array}$ \\
\hline 2014 & Integrated Reporting Framework by the IIRC \\
\hline 2014 & $\begin{array}{l}\text { EU Directive 2014/95/EU, which requires inclusion of a non-financial statement, containing relevant information on HR } \\
\text { policies and due diligence, outcomes of these policies, principal HR-risks and how to manage those, or an explanation } \\
\text { why not included }\end{array}$ \\
\hline 2015 & 2013/34/EU included in Dutch Civil Code (Titel 9 BW2). Comply or explain basis. \\
\hline 2016 & $\begin{array}{l}\text { Dutch Banking Sector Agreement on international responsible business conduct regarding HR (agreement on adherence to } \\
\text { OECD and UNGP) }\end{array}$ \\
\hline 2017 & 2014/95/EU included in Dutch Civil Code (Titel 9 BW2). Comply or explain basis. \\
\hline 2017 & $\begin{array}{l}\text { Dutch Corporate Governance Code approved (announced 2016): management report contains vision and strategy on } \\
\text { long term value creation, including HR. Comply or explain basis. }\end{array}$ \\
\hline 2018 & Agreement on International Responsible Investment in the insurance sector. \\
\hline
\end{tabular}

Notes: The inclusion of mandatory reporting regulations in the Netherlands are expressed emphasised in bold; Announcements of regulations are emphasised in bold and italic. 
Figure 2. 'Human Rights' word count per report per financial year (per 10,000 words). Notes: Graph shows the number of times the term 'human rights' [or Dutch equivalent 'mensenrechten'] is mentioned in the report for that financial year, per 10,000 words. Panel 1 only includes the main reports (Annual Report or Integrated Report) of each firm (maximum 1 per year); Panel (2) also includes sustainability reports for the years in which the firm did not publish an integrated report.

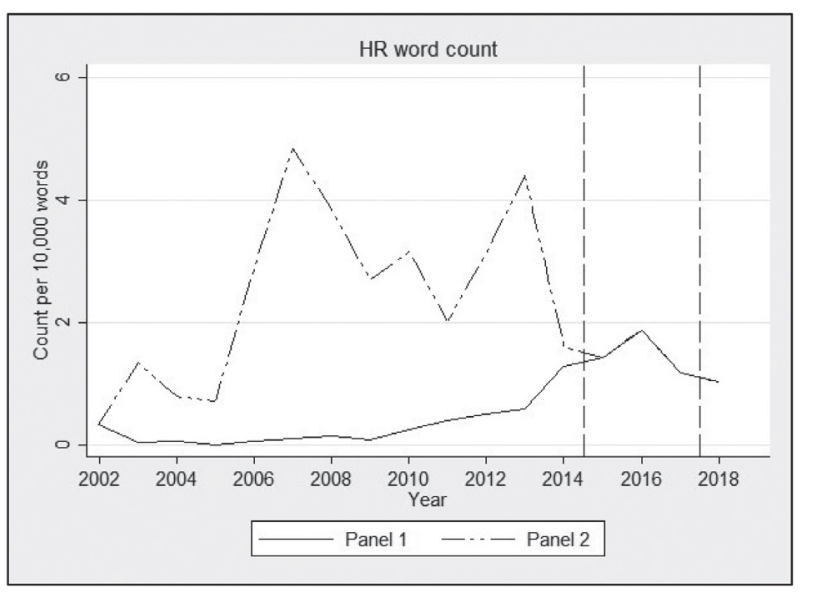

Figure 3. Human Rights index score in annual reports per financial year. Notes: Graph shows the number of times a word from the 'human rights' dictionary developed by Pencle and Mălăescu (2016) is mentioned in the report for that financial year, per 10,000 words. Panel 1 only includes the main reports (Annual Report or Integrated Report) of each firm (maximum 1 per year); Panel (2) also includes sustainability reports for the years in which the firm did not publish an integrated report.

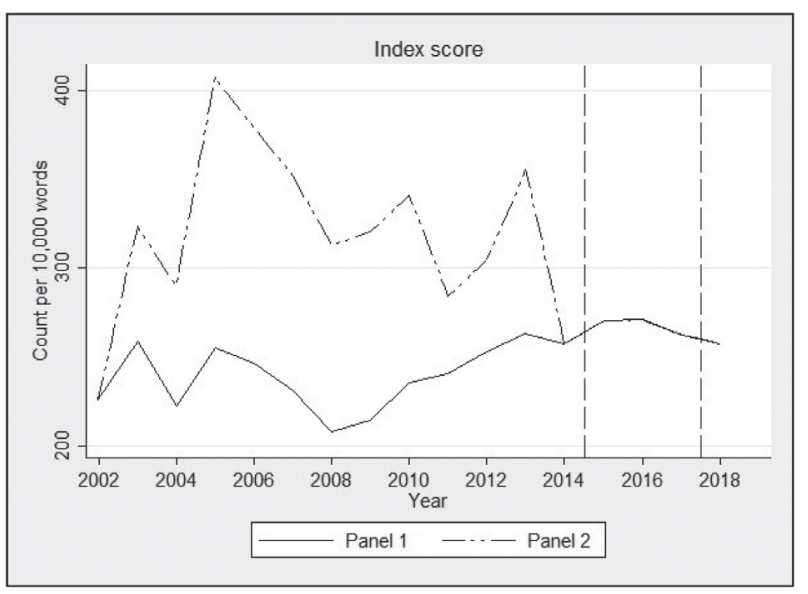

Civil Code, respectively. If The Directive were an exogenous shock, one would expect a cut in the time trend here. We do not observe that in this graph.

Figure 2 and 3 explore whether the extensiveness of human rights reporting has increased over time. Both figures show separate curves for Panel 1, which includes annual and integrated reports only, and Panel 2, which also includes sustainability reports. Figure 2 shows that the number of times 'human rights' was mentioned in the annual reports, increased over time. Overall, however, mentions of human rights are scarce: Even at the peak in 2016, less than 2 words per 10,000 words in an annual report were devoted to human rights. The trend is different when including the sustainability reports. Panel 2 indicates that most of the reporting on human rights was included in sustainability reports. After 2014, most companies stopped publishing sustainability reports and switched to integrated reporting, which significantly affected the total annual reporting on human rights. We also observe an increase in human rights reporting in Panel 1 after 2014, indicating that some of the human rights reporting switched to the integrated report. This might also be influenced by The Directive, which compels companies to report on human rights in their annual report.

Figure 3 shows the alternative measure for the extensiveness of human rights reporting we use the Pencle and Mălăescu index. It shows a similar trend as Figure 2. There is an upward time trend visible that behaves less erratically than the human rights count (except around 2008), but show otherwise the same pattern, including the sharp decrease in overall human rights reporting (Panel 2) after 2014.

\subsection{The marginal effect of mandatory reporting}

Now that we have a better understanding of the institutional pressures and the increasing trend of reporting on human rights over the past two decades, we are able to explore the marginal effect of the new EU Directive. We estimate the effect by comparing the means in annual reporting before and after the announcement date. Table 4 shows the results of this analysis. Panel 1 shows the average reporting on human rights in the annual reports in our sample before and after the announcement; Panel 2 does the same, but includes sustainability reports. Column (1) and (2) include data from 2013 to 2016two years before and after the announcement, Column (3) and (4) include data from 2012 to 2017-three years before and after the announcement, Column (5) and (6) include data from 2011 to 2018-four years before and after the announcement.

Table 4 shows some interesting developments after the announcement. First, the proportion of reports that mention human rights increases significantly, whether the sustainability reports are included or not. After 2014, all companies in our sample mention human rights in their annual reporting. Second, the human rights count increases in the annual reports, but overall-including the sustainability reports - there is no significant change. We also find no significant changes in the human rights index scores.

Nevertheless, the analysis in Table 4 merely shows the changes before and after a certain cut-off point in time. We have established that in the Dutch financial sector, a variety of intuitional forces have driven reporting standards over the past two decades, resulting in a steady increase in trend in human rights reporting. If The Directive is regarded as an exogenous shock in human rights reporting, it should affect human rights reporting independently of this trend. Hence, a more accurate estimation of the 
Table 4. Human rights reporting (means) before and after year of announcement of EU Directive (2014).

\begin{tabular}{|c|c|c|c|c|c|c|}
\hline & \multicolumn{2}{|c|}{ +/- 2 years } & \multicolumn{2}{|c|}{$+/-3$ years } & \multicolumn{2}{|c|}{$+/-4$ years } \\
\hline & $\begin{array}{c}\text { Before } \\
\text { (1) }\end{array}$ & $\begin{array}{l}\text { After } \\
(2)\end{array}$ & $\begin{array}{c}\text { Before } \\
\text { (3) }\end{array}$ & $\begin{array}{l}\text { After } \\
(4)\end{array}$ & $\begin{array}{c}\text { Before } \\
\text { (5) }\end{array}$ & $\begin{array}{c}\text { After } \\
(6)\end{array}$ \\
\hline \multicolumn{7}{|l|}{ Panel 1} \\
\hline Human rights $(\mathrm{y} / \mathrm{n})$ & $\begin{array}{c}0.8 \\
(0.1)\end{array}$ & $\begin{array}{l}1.0 * * \\
(0.0)\end{array}$ & $\begin{array}{c}0.7 \\
(0.1)\end{array}$ & $\begin{array}{c}1.0 * * * \\
(0.0)\end{array}$ & $\begin{array}{c}0.7 \\
(0.1)\end{array}$ & $\begin{array}{c}1.0 * * * \\
(0.0)\end{array}$ \\
\hline HR count per 10,000 words & $\begin{array}{c}0.9 \\
(0.5)\end{array}$ & $\begin{array}{c}1.6 \\
(0.5)\end{array}$ & $\begin{array}{c}0.8 \\
(0.3)\end{array}$ & $\begin{array}{c}1.5 \\
(0.3)\end{array}$ & $\begin{array}{c}0.7 \\
(0.2)\end{array}$ & $\begin{array}{c}1.4 \\
(0.3)\end{array}$ \\
\hline HR index & $\begin{array}{l}260.0 \\
(12.3)\end{array}$ & $\begin{array}{l}270.4 \\
(11.3)\end{array}$ & $\begin{array}{c}257.6 \\
(9.5)\end{array}$ & $\begin{array}{c}267.7 \\
(8.2)\end{array}$ & $\begin{array}{c}253.3 \\
(7.4)\end{array}$ & $\begin{array}{c}265.2 \\
(6.4)\end{array}$ \\
\hline Observations & 16 & 16 & 24 & 24 & 32 & 32 \\
\hline Panel 2 & & & & & & \\
\hline Human rights $(\mathrm{y} / \mathrm{n})$ & $\begin{array}{c}0.8 \\
(0.1)\end{array}$ & $\begin{array}{l}1.0 * * \\
(0.0)\end{array}$ & $\begin{array}{c}0.8 \\
(0.1)\end{array}$ & $\begin{array}{c}1.0 * * * \\
(0.0)\end{array}$ & $\begin{array}{c}0.8 \\
(0.1)\end{array}$ & $\begin{array}{c}1.0 * * * \\
(0.0)\end{array}$ \\
\hline HR count per 10,000 words & $\begin{array}{c}2.4 \\
(0.9)\end{array}$ & $\begin{array}{c}1.6 \\
(0.5)\end{array}$ & $\begin{array}{c}2.4 \\
(0.7)\end{array}$ & $\begin{array}{c}1.5 \\
(0.3)\end{array}$ & $\begin{array}{c}2.2 \\
(0.6)\end{array}$ & $\begin{array}{l}1.4^{*} \\
(0.3)\end{array}$ \\
\hline HR index & $\begin{array}{l}272.1 \\
(13.8)\end{array}$ & $\begin{array}{l}270.4 \\
(11.3)\end{array}$ & $\begin{array}{l}271.6 \\
(11.5)\end{array}$ & $\begin{array}{c}267.7 \\
(8.2)\end{array}$ & $\begin{array}{l}266.7 \\
(9.3)\end{array}$ & $\begin{array}{c}265.2 \\
(6.4)\end{array}$ \\
\hline Observations & $20 / 18^{\mathrm{a}}$ & 16 & $31 / 27^{\mathrm{a}}$ & 24 & $41 / 36^{\mathrm{a}}$ & 32 \\
\hline
\end{tabular}

Notes: Standard errors in parentheses. Dependent variables in Panel 1 are computed based on the primary annual reports (Annual, or Integrated Reports) only, whereas the dependent variables in Panel 2 also includes sustainability reports for the years in which the annual report is not an integrated report. Significance level of estimated differences calculated using t-tests: ${ }^{* * *} \mathrm{p}<0.01 ; * * \mathrm{p}<0.05 ;{ }^{*} \mathrm{p}<0.10$. ${ }^{a}$ Observations included for HR index are lower due the exclusion of non-English reports.

Table 5. OLS estimates on the marginal effect of The Directive on HR reporting.

\begin{tabular}{|c|c|c|c|c|c|c|}
\hline \multirow[t]{2}{*}{ DV: } & \multicolumn{3}{|c|}{ HR count (Panel 1) } & \multicolumn{3}{|c|}{ HR count (Panel 2) } \\
\hline & (1) & (2) & (3) & (4) & (5) & (6) \\
\hline \multirow[t]{2}{*}{ 2014/95/EU announced } & 0.17 & & 0.16 & -0.07 & & -0.08 \\
\hline & $(0.14)$ & & $(0.13)$ & $(0.30)$ & & $(0.27)$ \\
\hline \multirow[t]{2}{*}{ 2014/95/EU implemented } & & -0.05 & -0.02 & & -0.24 & -0.25 \\
\hline & & $(0.15)$ & $(0.14)$ & & $(0.31)$ & $(0.29)$ \\
\hline \multirow[t]{2}{*}{ Year } & $0.05 * * *$ & $0.05 * * *$ & $0.05 * * *$ & $0.03 * *$ & $0.04 * *$ & $0.04 * * *$ \\
\hline & $(0.01)$ & $(0.01)$ & $(0.01)$ & $(0.01)$ & $(0.01)$ & $(0.01)$ \\
\hline Firm fixed effects & No & No & Yes & No & No & Yes \\
\hline Observations & 135 & 135 & 135 & 167 & 167 & 167 \\
\hline Adjusted R-squared & 0.30 & 0.29 & 0.43 & 0.02 & 0.03 & 0.21 \\
\hline
\end{tabular}

Notes: Dependent variables expressed as the natural log of HR counts per 10,000 words. Panel 1 only includes the main annual reports (Annual, or Integrated Report) of each firm (maximum 1 per year); Panel 2 also includes sustainability reports for the years in which the firm did not publish an integrated report. Standard errors in parentheses $* * * \mathrm{p}<0.01 ; * * \mathrm{p}<0.05$

marginal effect of The Directive can be obtained with an OLS-estimation controlling for the trends over time:

$$
H R_{i t}=\alpha+\beta_{1} \text { Directive }_{t}+\beta_{2} \text { Year }+\varepsilon_{i t}
$$

In this equation $H R_{i t}$ is natural logarithm of the 'human rights' count of company $i$ in annual report of year $t$; and $A_{t}$ a dummy variable equal to 1 if The Directive was first implemented for administrative year $t$ or 0 otherwise. Variable Year represents the year of the annual report and parameter $\beta_{2}$ the trend in human rights reporting over time.

The results of this analysis are shown in Table 5. Column (1) shows the estimates of the effect on the announcement of The Directive, Column (2) shows the effect of the implementation of The Directive and Column (3) shows the estimates of the full model including firm-fixed effect. Columns (4)-(6) follow the same structure but include the sustainability reports.

The estimates in Table 5 confirm our other analyses. There is a significant time trend in human rights report- ing over the years, regardless of whether sustainability reports are included. However, when we control for this time trend, we find no significant effect of either the announcement or the implementation of The Directive.

\section{Conclusion}

While the introduction of The Directive is often considered 'an unprecedented act of supra-national disclosure regulation' (Fiechter et al. 2018, p. 9), our analysis illustrates that its potential effect on reporting should not be overstated. Analysing the introduction of The Directive from an institutional perspective, we find that changes in human rights reporting that occurred after its introduction may be better explained by an increasing trend over time than by The Directive itself. Our analysis of 17 years of annual reporting of financial institutions shows a steady linear increase in the extensiveness of human rights reporting, 
with no strong deviations during the introduction of The Directive. Unfortunately, given the scope of our research, we cannot assess the quality of the reporting over time.

This study is exploratory. Our sample is relatively small and we should be careful with generalising the results. However, our results imply that, in our sample of financial institutions, The Directive is itself as much a consequence of the institutional context as the reporting practices of the companies are, and is therefore inherently endogenous. This implies that analysing the effects of mandatory re- porting via a simple pre-post analyse would give an overestimation of the effect. As with any empirical study, this study has its limitations. First, the sample includes both companies with an international, and (albeit only few) companies with a more national focus; this may have caused a deflated human rights disclosure score. Second, it was not feasible to analyse the reports in more detail, to get an impression on the context of human rights disclosure. This could be an interesting addition for future research, as well as the inclusion of SME's, or other sectors.

- Dr. F. Hubers is assistant professor, Faculty of Management at Open Universiteit

Dr. T. Thijssens is assistant professor, Faculty of Management at Open Universiteit.

\section{Note}

1. Specifically, memoranda of the secretary of state to the house of representatives kst 26485-14 (2001) (https://zoek.officielebekendmakingen. nl/kst-26485-14) and kst 26485-86 (2010) (https://zoek.officielebekendmakingen.nl/kst-26485-86.html), and report b-20644 of the Ministry of the Interior and Kingdom Relations (Ministerie van Binnenlandse Zaken en Koninkrijksrelaties (2013) Nationaal actieplan mensenrechten).

\section{References}

- Ali W, Frynas JG (2018) The role of normative CSR-promoting institutions in stimulating CSR disclosures in developing countries. Corporate Social Responsibility and Environmental Management 25(4): 373-390. https://doi.org/10.1002/csr.1466

- Bebbington J, Higgins C, Frame B (2009). Initiating sustainable development reporting: Evidence from New Zealand. Accounting, Auditing \& Accountability Journal 22(4): 588-625. https://doi. org/10.1108/09513570910955452

- Bhimani A, Silvola H, Sivabalan P (2016) Voluntary corporate social responsibility reporting: A study of early and late reporter motivations and outcomes. Journal of Management Accounting Research 28(2): 77-101. https://doi.org/10.2308/jmar-51440

- Bondy K, Moon J, Matten D (2012) An institution of corporate social responsibility (CSR) in multi-national corporations (MNCs): Form and implications. Journal of Business Ethics 111(2): 281-299. https://doi.org/10.1007/s10551-012-1208-7

- Campbell JL (2006) Institutional analysis and the paradox of corporate social responsibility. American Behavioral Scientist 49(7): 925-938. https://doi.org/10.1177/0002764205285172

- Carini C, Rocca L, Veneziani M, Teodori C (2018) Ex-ante impact assessment of sustainability information-the Directive 2014/95. Sustainability 10(2): 560. https://doi.org/10.3390/su10020560

- Christ KL, Rao KK, Burritt RL (2019) Accounting for modern slavery: an analysis of Australian listed company disclosures. Accounting, Auditing \& Accountability Journal 32(3): 836-865. https://doi. org/10.1108/AAAJ-11-2017-3242

- Cubilla-Montilla M, Nieto-Librero AB, Galindo-Villardón MP, Vicente Galindo MP, Garcia-Sanchez IM (2019) Are cultural values sufficient to improve stakeholder engagement human and labour rights issues? Corporate Social Responsibility and Environmental Management 26(4): 938-955. https://doi.org/10.1002/csr.1733
De Villiers C, Alexander D (2014) The institutionalisation of corporate social responsibility reporting. The British Accounting Review 46(2): 198-212. https://doi.org/10.1016/j.bar.2014.03.001

- DiMaggio PJ, Powell WW (1983) The iron cage revisited: Institutional isomorphism and collective rationality in organizational fields. American Sociological Review 48(2): 147-160. https://doi. org/10.2307/2095101

- DNB [De Nederlandsche Bank] (2019) Op waarde geschat? Duurzaamheidsrisico's en -doelen in de Nederlandse financiële sector. De Nederlandsche Bank (Amsterdam). https://www.dnb.nl/binaries/ Rapport\%20'Op\%20waarde\%20geschat.\%20Duurzaamheidsrisico's\%20en\%20-doelen_tcm46-381617.pdf

- Doh JP, Guay TR (2006) Corporate social responsibility, public policy, and NGO activism in Europe and the United States: An institutional-stakeholder perspective. Journal of Management Studies 43(1): 47-73. https://doi.org/10.1111/j.1467-6486.2006.00582.x

- Fiechter P, Hitz JM, Lehmann N (2018) Real effects in anticipation of mandatory disclosures: Evidence from the European Union's CSR Directive. https://doi.org/10.2139/ssrn.3033883

- Gallego-Álvarez I, Quina-Custodio IA (2017) Corporate social responsibility reporting and varieties of capitalism: An international analysis of state-led and liberal market economies. Corporate Social Responsibility and Environmental Management 24(6): 478-495. https://doi.org/10.1002/csr.1421

- Grewal J, Riedl EJ, Serafeim G (2019) Market reaction to mandatory nonfinancial disclosure. Management Science 65(7): 3061-3084. https://doi.org/10.1287/mnsc.2018.3099

- Healy PM, Palepu KG (2001) Information asymmetry, corporate disclosure, and the capital markets: A review of the empirical disclosure literature. Journal of Accounting and Economics 31(1-3): 405-440. https://doi.org/10.1016/S0165-4101(01)00018-0 
- Herremans IM, Nazari JA (2016) Sustainability reporting driving forces and management control systems. Journal of Management Accounting Research 28(2): 103-124. https://doi.org/10.2308/jmar-51470

- Higgins C, Stubbs W, Milne M (2018) Is sustainability reporting becoming institutionalised? The role of an issues-based field. Journal of Business Ethics 147(2): 309-326. https://doi.org/10.1007/s10551015-2931-7

- Husted BW, Allen DB (2006) Corporate social responsibility in the multinational enterprise: Strategic and institutional approaches. Journal of International Business Studies 37(6): 838-849. https:// doi.org/10.1057/palgrave.jibs.8400227

- Ioannou I, Serafeim G (2019a) The consequences of mandatory corporate sustainability reporting. In: McWilliams A, Rupp DE, Siegel DS, Stahl GK, Waldman (DA) (Eds) The Oxford Handbook of Corporate Social Responsibility: Psychological and organizational perspectives. Oxford University Press, Oxford, 452-489. https://doi. org/10.1093/oxfordhb/9780198802280.013.20

- Ioannou I, Serafeim G (2019b) Corporate sustainability: A strategy? Harvard Business School Accounting \& Management Unit Working Paper 19-065. https://www.hbs.edu/faculty/Publication\%20 Files/19-065_16deb9d6-4461-4d2f-8bbe-2c74b5beffb8.pdf

- Islam MA (2011) Human rights performance reporting: a study of corporations within Australian financial sector. In Proceedings of the 2011 Critical Perspectives on Accounting conference. Elsevier, 1-29. http://mams.rmit.edu.au/h8y65rw6ryrvz.pdf

- Islam MA, McPhail K (2011) Regulating for corporate human rights abuses: The emergence of corporate reporting on the ILO's human rights standards within the global garment manufacturing and retail industry. Critical Perspectives on Accounting 22(8): 790-810. https://doi.org/10.1016/j.cpa.2011.07.003

- Islam MA, Van Staden CJ (2018) Social movement NGOs and the comprehensiveness of conflict mineral disclosures: evidence from global companies. Accounting, Organizations and Society 65: 1-19. https://doi.org/10.1016/j.aos.2017.11.002

- Jackson G, Apostolakou A (2010) Corporate social responsibility in Western Europe: an institutional mirror or substitute? Journal of Business Ethics 94(3): 371-394. https://doi.org/10.1007/s10551009-0269-8

- Kolk A, Walhain S, Van de Wateringen, S (2001) Environmental reporting by the Fortune Global 250: exploring the influence of nationality and sector. Business strategy and the environment 10(1): 15-28. https://doi.org/10.1002/1099-0836(200101/02)10:1\%3C15::AIDBSE275\%3E3.0.CO;2-Y

- KPMG (2017) The KPMG Survey of Corporate Responsibility Reporting 2017. KPMG (Amsterdam). https://home.kpmg/be/en/home/ insights/2017/10/the-kpmg-survey-of-corporate-responsibility-reporting-2017.html

- KPMG, GRI, UNEP, CCGA (2016) Carrots \& Sticks: Global trends in sustainability reporting regulation and policy. https://assets.kpmg.com/ content/dam/kpmg/pdf/2016/05/carrots-and-sticks-may-2016.pdf

- Larrinaga C (2007) Sustainability reporting: Insights from neo-institutional theory. In: Unerman J, O’Dwyer B, Bebbington J (Eds) Sustainability accounting and accountability. Routledge, London.

- McPhail K, Ferguson J (2016) The past, the present and the future of accounting for human rights. Accounting, Auditing \& Account- ability Journal 29(4): 526-541. https://doi.org/10.1108/AAAJ-032016-2441

- Ministerie van Binnenlandse Zaken en Koninkrijksrelaties (2013) Nationaal actieplan mensenrechten. https://www.rijksoverheid.nl/ onderwerpen/mensenrechten/documenten/publicaties/2013/12/10/ nationaal-actieplan-mensenrechten

- Nikolaeva R, Bicho M (2011) The role of institutional and reputational factors in the voluntary adoption of corporate social responsibility reporting standards. Journal of the Academy of Marketing Science 39(1): 136-157. https://doi.org/10.1007/s11747-010-0214-5

- OECD (2019) Due Diligence for Responsible Corporate Lending and Securities Underwriting: Key considerations for banks implementing the OECD Guidelines for Multinational Enterprises. OECD (Geneva). http://mneguidelines.oecd.org/Due-Diligence-for-Responsible-Corporate-Lending-and-Securities-Underwriting.pdf

- Ortas E, Álvarez I, Jaussaud J, Garayar A (2015) The impact of institutional and social context on corporate environmental, social and governance performance of companies committed to voluntary corporate social responsibility initiatives. Journal of Cleaner Production 108: 673-684. https://doi.org/10.1016/j.jclepro.2015.06.089

- Pedersen ERG, Neergaard P, Pedersen JT, Gwozdz W (2013) Conformance and deviance: Company responses to institutional pressures for corporate social responsibility reporting. Business Strategy and the Environment 22(6): 357-373. https://doi.org/10.1002/ bse. 1743

- Pencle N, Mălăescu I (2016) What's in the words? Development and validation of a multidimensional dictionary for CSR and application using prospectuses. Journal of Emerging Technologies in Accounting 13(2): 109-127. https://doi.org/10.2308/jeta-51615

- Ruggie J (2008) Protect, respect and remedy: A framework for business and human rights. Innovations: Technology, Governance, Globalization 3(2): 189-212. https://doi.org/10.1162/itgg.2008.3.2.189

- Ruggie JG (2007) Business and human rights: the evolving international agenda. American Journal of International Law 101(4): 819-840. https://doi.org/10.2139/ssrn.976547

- Shabana KM, Buchholtz AK, Carroll AB (2017) The institutionalization of corporate social responsibility reporting. Business \& Society 56(8): 1107-1135. https://doi.org/10.1177/0007650316628177

- UN (2011) Guiding Principles on Business and Human Rights. New York and Geneva United Nations Human Rights Office of the High Commissioner. https://www.business-humanrights.org/en/un-guiding-principles

- Verrecchia R (2001) Essays on disclosure. Journal of Accounting and Economics 32: 97-180. https://doi.org/10.1016/S01654101(01)00025-8

- Witt MA, Miska C (2019) Institutions and Corporate Social Responsibility. In McWilliams A, Rupp D, Siegel D, Stahl GK, Waldman D (Eds.) The Oxford Handbook of Corporate Social Responsibility: Psychological and Organizational Perspectives. Oxford University Press, Oxford. https://doi.org/10.1093/oxfordhb/9780198802280.013.25

- Young S, Marais M (2012) A multi-level perspective of CSR Reporting: The implications of national institutions and industry risk characteristics. Corporate Governance: An International Review 20(5): 432-450. https://doi.org/10.1111/j.1467-8683.2012.00926.x 